\title{
Analysis of the Interaction between Pisum sativum L. and Rhizobium laguerreae Strains Nodulating This Legume in Northwest Spain
}

\author{
José David Flores-Félix ${ }^{1,+} \oplus$, Lorena Carro ${ }^{1} \oplus$, Eugenia Cerda-Castillo ${ }^{1, \ddagger}$, Andrea Squartini ${ }^{2}{ }^{\circledR}$, \\ Raúl Rivas $1,3,4$ and Encarna Velázquez ${ }^{1,3,4, *}$ \\ 1 Departamento de Microbiologíay Genética, Universidad de Salamanca, 37007 Salamanca, Spain; \\ jdflores@usal.es (J.D.F.-F.); lcg@usal.es (L.C.); eugenia.castillo@ct.unanleon.edu.ni (E.C.-C.); \\ raulrg@usal.es (R.R.) \\ 2 Department of Agronomy, Food, Natural Resources, Animals and Environment, University of Padova, \\ 35020 Legnaro, Italy; squart@unipd.it \\ 3 Instituto Hispanoluso de Investigaciones Agrarias, 37007 Salamanca, Spain \\ 4 Unidad Asociada USAL-IRNASA, 37007 Salamanca, Spain \\ * Correspondence: evp@usal.es; Tel.: +349-2329-4532 \\ † Present address: CICS-UBI-Health Sciences Research Centre, University of Beira Interior, \\ 6200-506 Covilhã, Portugal. \\ $\ddagger$ Present address: Departamento de Biología, Facultad de Ciencia y Tecnología, Universidad Nacional \\ Autónoma de Nicaragua, León 21000, Nicaragua.
}

Received: 3 November 2020; Accepted: 9 December 2020; Published: 11 December 2020

\begin{abstract}
Pisum sativum L. (pea) is one of the most cultivated grain legumes in European countries due to the high protein content of its seeds. Nevertheless, the rhizobial microsymbionts of this legume have been scarcely studied in these countries. In this work, we analyzed the rhizobial strains nodulating the pea in a region from Northwestern Spain, where this legume is widely cultivated. The isolated strains were genetically diverse, and the phylogenetic analysis of core and symbiotic genes showed that these strains belong to different clusters related to $R$. laguerreae sv. viciae. Representative strains of these clusters were able to produce cellulose and cellulases, which are two key molecules in the legume infection process. They formed biofilms and produced acyl-homoserine lactones (AHLs), which are involved in the quorum sensing regulation process. They also exhibited several plant growth promotion mechanisms, including phosphate solubilization, siderophore, and indole acetic acid production and symbiotic atmospheric nitrogen fixation. All strains showed high symbiotic efficiency on pea plants, indicating that strains of R. laguerreae sv. viciae are promising candidates for the biofertilization of this legume worldwide.
\end{abstract}

Keywords: pea; Pisum sativum; Rhizobium laguerreae; symbiosis; quorum sensing; nodulation effectiveness; nitrogen fixation

\section{Introduction}

Pisum sativum L. (pea) is one of the most cultivated legumes worldwide due to the high protein content and quality of its seeds [1], with a cultivated area higher than 8 million ha and a production of over 16 million tonnes per year, about $44 \%$ of which corresponds to Europe [2]. Spain is within the top 10 countries producing dry peas, with a production in 2018 of 262,567 tonnes of dry peas and 109,270 tonnes of green peas. Around 30\% were produced in the Castilla y León region, the Valladolid province being the highest producer of dry peas within this region with 39,980 tonnes (52\% of the total production) according to the Spanish Ministry of Agriculture, Fishing and Food 
(https://www.mapa.gob.es/es/estadistica/temas/publicaciones/anuario-de-estadistica/2019/ default.aspx) [3].

Like other legumes, P. sativum establishes symbiosis with fast-growing rhizobia, particularly with species within the genus Rhizobium, which encompasses several species whose type strains were originally isolated from P. sativum nodules, such as Rhizobium leguminosarum [4], Rhizobium pisi [5], Rhizobium indicum [6], and Rhizobium ruizarguesonis [7]. Of these, only the strains from R. ruizarguesonis have been isolated in European countries such as Italy and Germany [7]. In the case of Rhizobium anhuiense, although the type strain was isolated from Vicia faba nodules, several strains isolated from P. sativum nodules were included in its original description [8].

Although the diversity of rhizobia nodulating P. sativum in some countries has been analyzed in the last decade [9-15], the endosymbionts of this legume have scarcely been studied in Spain, despite the economic importance of pea crops in this country. Some strains isolated from pea nodules in Central Spain were identified as R. leguminosarum on the basis of $r r s$ gene (16S rRNA) sequence analysis [10] and other strains isolated in Northwestern Spain were identified as R. leguminosarum or R. laguerreae by MALDI-TOF MS analysis [12]. Of these strains, the nodulation genes have only been analyzed for the R. leguminosarum strains isolated in Central Spain, which belong to the symbiovar viciae [10]. The type strains of the previously mentioned species, R. leguminosarum, R. pisi, R. anhuiense, and R. ruizarguesonis also belong to this symbiovar. Moreover, strains of this symbiovar linked to $R$. leguminosarum and $R$. laguerreae have been found in P. sativum nodules in Turkey [11] and Morocco [15].

The interaction between P. sativum and different strains of the species R. leguminosarum has been widely studied since the proposal of this bacterial name for pea nodulating bacteria [4]. However, the interaction between this legume and other more recently described Rhizobium species has been scarcely studied. Therefore, the objectives of this work were (i) an analysis of the diversity of $R$. laguerreae strains nodulating P. sativum in a soil from Northwest Spain, (ii) an analysis of their phylogenetic relationships with strains of $R$. laguerreae isolated in other geographical locations and from other legume hosts on the basis of core and symbiotic genes, (iii) a study of the ability to form biofilms in abiotic surfaces, of the production of molecules involved in the colonization of $P$. sativum, of quorum sensing, and of plant growth promotion, and (iv) an evaluation of the effectiveness of these strains on pea plants.

\section{Results and Discussion}

\subsection{RAPD Fingerprinting}

The RAPD fingerprinting has been widely used for the diversity analysis of fast-growing rhizobia, particularly those isolated from different legumes of the Vicia cross-nodulation group [16-20]. Therefore, we analyzed the RAPD patterns displayed by 24 rhizobial strains isolated from P. sativum nodules [12]. The results of this analysis showed that the strains from this study were genetically diverse and distributed into six groups with similarity values lower than $70 \%$ (Figure 1 ). A representative strain from each one of these groups was subjected to gene sequencing.

\subsection{Analysis of the rrs Gene}

The rrs gene has been sequenced in many strains nodulating Pisum and other legumes from the same cross-inoculation group, such as Vicia, Lens, and Lathyrus, some of them isolated in different Spanish regions [20,21]. These strains belong to the phylogenetic group of $R$. leguminosarum, which contains several species whose type strains have identical rrs genes (Figure 2). However, slight differences have been found in the rrs gene sequences of other strains as in the case of strains belonging to the species $R$. laguerreae in which some strains harbored an insert of about $70 \mathrm{bp}$ at the beginning of their $r$ rs genes [21]. The results of this study showed that the analyzed strains belong to different phylogenetic clusters, each of which also contain other strains isolated from Pisum, Vicia, or Lens in different countries and continents (Figure 2). 


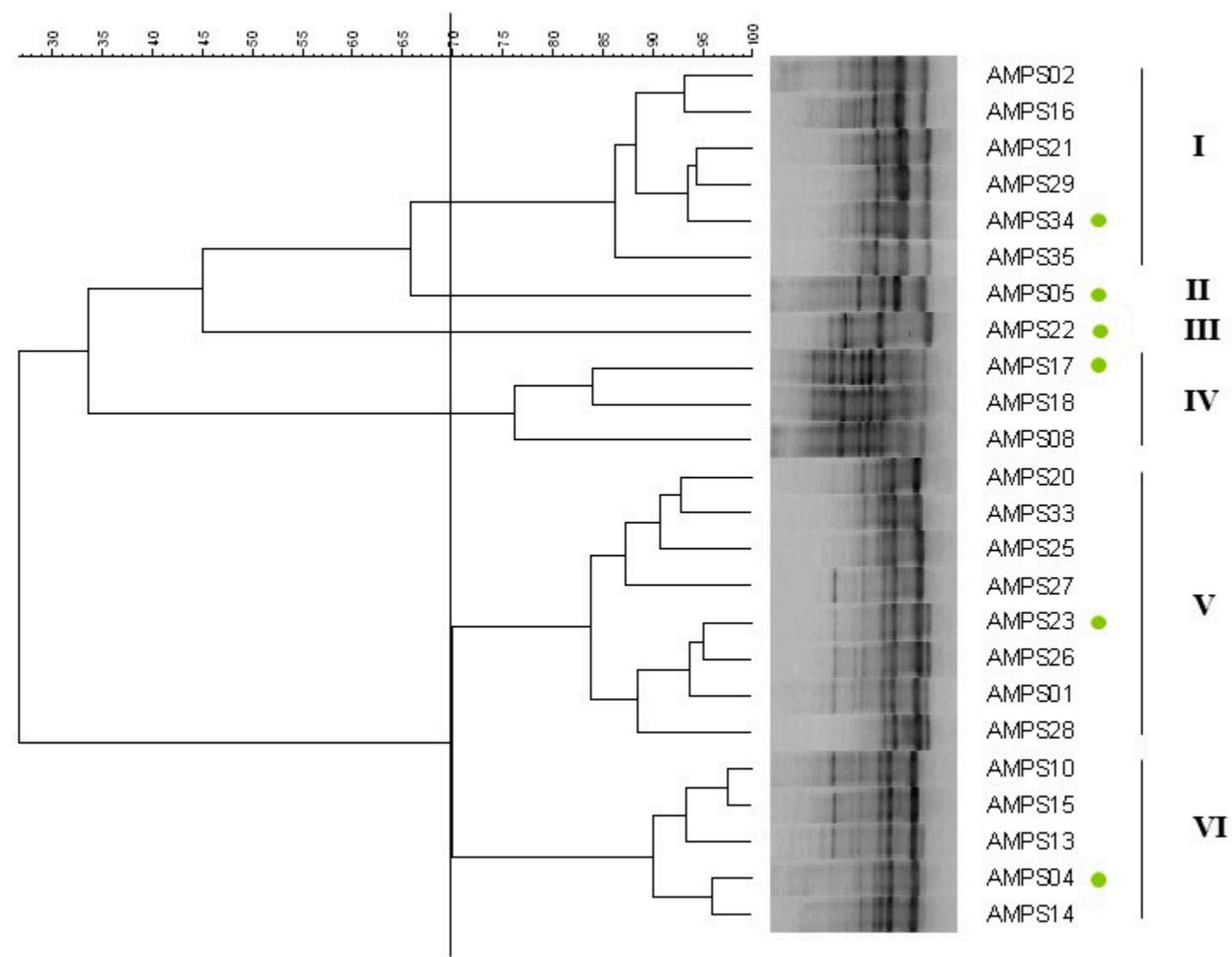

Figure 1. Dendrogram obtained for the strains of this study using Pearson's coefficient and UPGMA (Unweighted Pair Group Method with Arithmetic Mean) analysis of the RAPD profiles. Filled green circles indicated the strains selected from different RAPD groups for the remaining analysis of this study.

All strains from this study presented differences in their $r r s$ genes with respect to those of the type strains of the species from the R. leguminosarum group. Concretely, the rrs genes of the strains AMPS34, AMPS17, AMPS23, and AMPS04, representative of RAPD groups I, IV, V, and VI, respectively, have two different nucleotides with respect to these strains (positions 942 and 955, taking the rrs gene sequence of $R$. laguerreae $\mathrm{FB206}^{\mathrm{T}}$ with accession number JN558651 as a reference). The rrs gene sequences of these strains were identical to those of several strains of R. laguerreae isolated from nodules of Vicia and Lens in different countries, highlighting the strain MLS17 isolated from nodules of L. culinaris in Spain [21] and the strain FB403 included in the original description of R. laguerreae, which was isolated from $V$. faba nodules in Tunisia [22]. The $r$ rs gene sequence of strain AMPS05, representative of RAPD type II, presented four different nucleotides (positions 67, 69, 942, and 955) and contains an intervening sequence (IVS) of about $70 \mathrm{bp}$ located at the beginning of this gene between nucleotides 70 and 143. The $r r s$ gene sequence and the IVS of strain AMPS05 were identical to those found in strains R. laguerreae MLS05 and MLSC04, which nodulated L. culinaris in Spain [21], in strain CVIII4, included in the original description of R. laguerreae, which nodulated V. sativa in Spain [22], and in other strains isolated from nodules of Pisum, Vicia, and Lens in different countries (Figure 2). Finally, the rrs gene sequence of strain AMPS22, representative of RAPD group III, has a different nucleotide at the position 1070, and it was identical to those of two strains isolated from nodules of P. sativum in India and a strain isolated from the same host in Russia (Figure 2). 


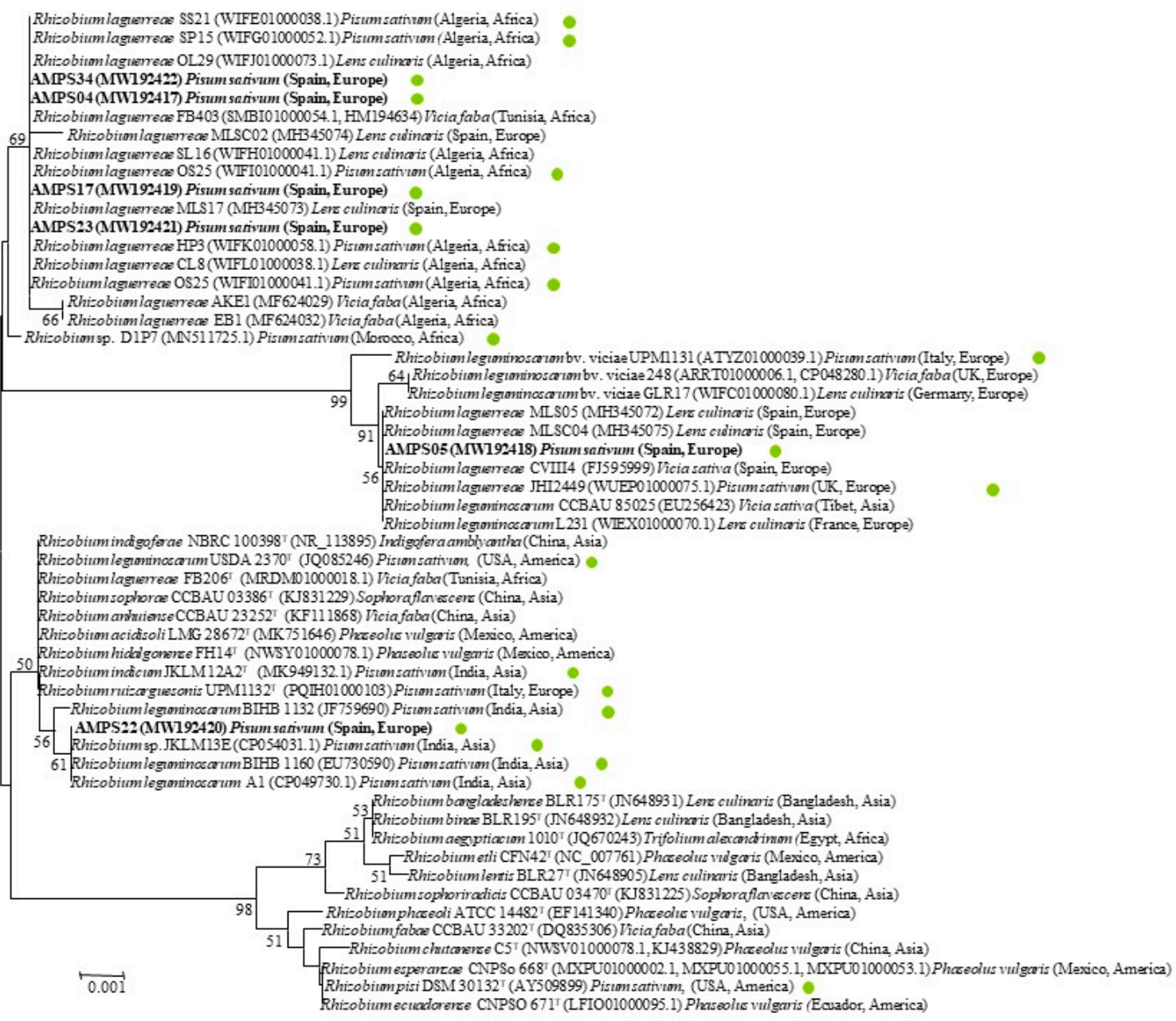

Figure 2. Neighbor-joining unrooted phylogenetic tree based on $r r s$ gene sequences (1340 nt) showing the taxonomic location of representative strains from different groups of RAPD within the genus Rhizobium. Bootstrap values calculated for 1000 replications are indicated. Bar: $1 \mathrm{nt}$ substitution per $1000 \mathrm{nt}$. Filled green circles indicated the strains isolated from Pisum sativum worldwide.

It is remarkable that, although most strains with rrs gene sequences identical to those of our strains have been assigned to the species $R$. laguerreae, some of them are named $R$. leguminosarum or Rhizobium sp. The elucidation of the taxonomic affiliation of these strains cannot be based on the rrs gene sequences since they are identical in several type strains of different species, namely $R$. leguminosarum, $R$. laguerreae, $R$. anhuiense, $R$. sophorae, $R$. acidisoli, $R$. hidalgonense, $R$. ruizarguesonis, and $R$. indicum (Figure 2). It should be based on the analysis of housekeeping genes, such as rec $A$ and atpD, which allow us to differentiate among species with identical rrs gene sequences. In this study, we revised the affiliation of some of these strains for which the $\operatorname{rec} A$ and $a t p D$ gene sequences are currently available.

\subsection{Analysis of recA and atpD Genes}

The atpD and $r e c A$ genes were the first housekeeping genes applied to species differentiation within the family Rhizobiaceae [23] and therefore have been sequenced for the type strains of all Rhizobium species described to date, allowing for the assignment of new isolates to these species. In addition, their sequences are available for many other strains, particularly for those nodulating P. sativum and other legumes from the Vicia cross-inoculation group in different geographical locations (Figure 3). 


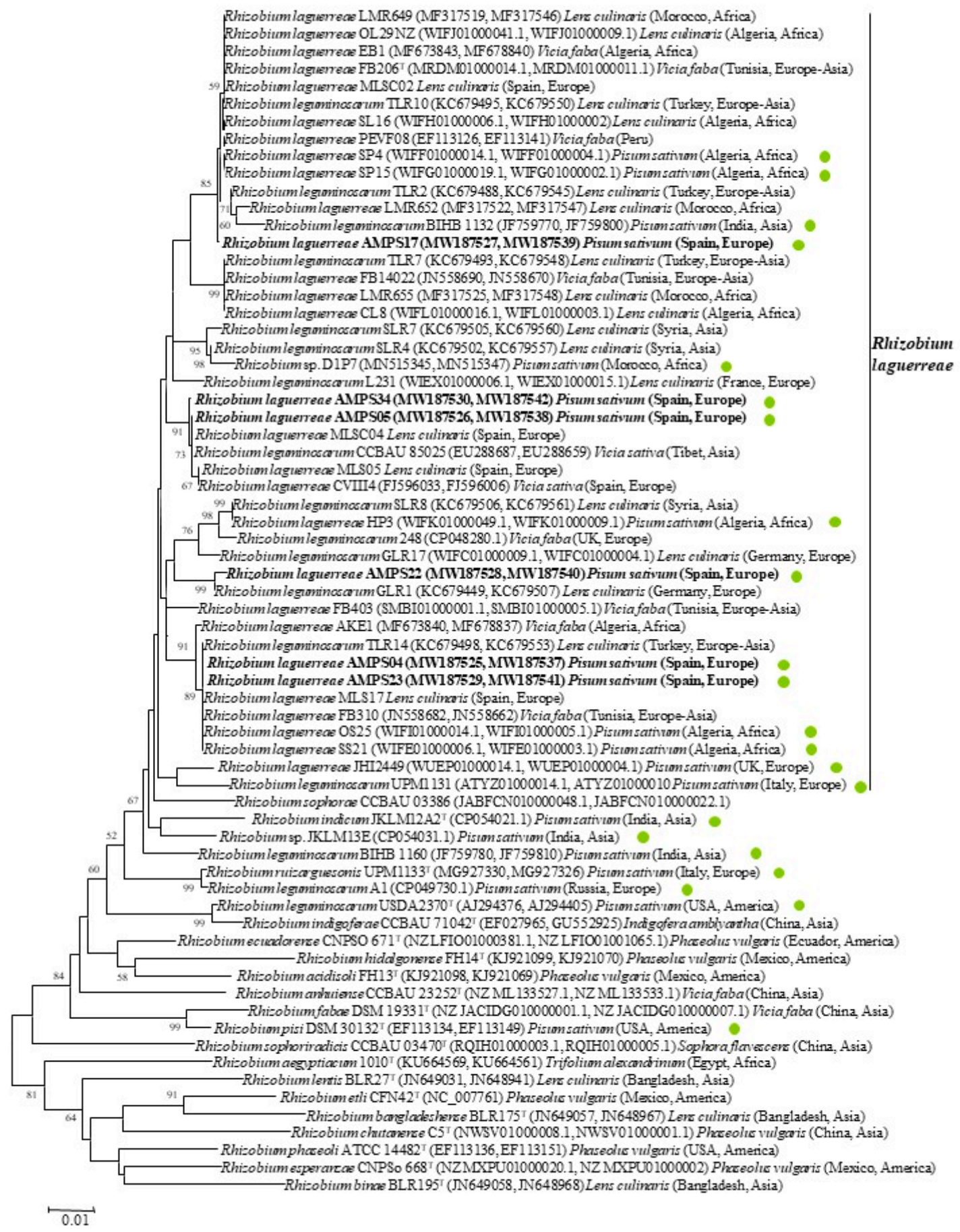

Figure 3. Neighbor-joining unrooted phylogenetic tree based on $\operatorname{rec} A$ and atpD concatenated gene sequences (728 nt) showing the position of representative strains from each group within genus Rhizobium. Bootstrap values calculated for 1000 replications are indicated. Bar: 1 nt substitution per $100 \mathrm{nt}$. Filled green circles indicated the strains isolated from Pisum sativum worldwide.

The results of the analysis of $\operatorname{rec} A$ and $\operatorname{atp} D$ genes showed that the strains analyzed in this work present similarity values higher than $96 \%$ and $98 \%$, respectively, with respect to the type strain of $R$. laguerreae (Table 1). These values showed that all of these strains belong to the species $R$. laguerreae, even though they matched with score values lower than 2.3 with the type strain of this species after MALDI-TOF MS analysis [12]. The phylogenetic analysis of the concatenated $\operatorname{rec} A$ and atpD genes 
showed that the analyzed strains belong to different clusters, some of which also contain strains included in the official description of the species R. laguerreae [22]. The strain AMPS17 belongs to the same phylogenetic cluster of the type strain of this species FB206 ${ }^{\mathrm{T}}$, strains AMPS05 and AMPS34 belong to that of the strain CVIII4, and strains AMPS04 and AMPS23 belong to that of the strain FB310 (Figure 3).

In the phylogenetic analysis of the $\operatorname{rec} A$ and atpD genes, we also included strains closely related to those from this study, when the sequences of these two genes are available at GenBank (Figure 3). Several of these strains isolated from nodules of Pisum, Vicia, and Lens, including those strains carrying an IVS in their rrs gene, have been named Rhizobium leguminosarum, but the analysis of their recA and $a t p D$ genes placed them within the species R. laguerreae (Figure 3). This analysis confirmed the phylogenetic complexity of this species, which was already shown at the time of its description, since it encompassed strains phylogenetically divergent [22] and led Flores-Félix et al. [21] to point out the existence of several genospecies within R. laguerreae after the analysis of several strains isolated from nodules of different legumes [21]. Nevertheless, in the present work, where we analyzed more strains from the phylogenetic group of $R$. laguerreae, we observed a high complexity within this species, indicating that it is difficult to establish reasonable limits for differentiating genospecies (or subspecies) and that it will be necessary to do so based on the analysis of whole genomes.

The strains nodulating P. sativum analyzed in this study fall within four clusters obtained after the $\operatorname{rec} A$ and $\operatorname{atpD}$ gene analysis that also contain other strains isolated in different countries from nodules of Lens, Vicia, and Pisum (Figure 3). Strain AMPS17 and strains AMPS04 and AMPS23 belong to two clusters, together with closely related strains, most of which are already named R. laguerreae and have been isolated in different countries of Asia, Africa, Europe, and America from nodules of L. culinaris (Turkey, Algeria, and Morocco), V. faba (Tunisia, Algeria, and Peru), and P. sativum (Algeria and India) $[9,15,17,22,24,25]$. Some of these strains were named $R$. leguminosarum at the time of their publication because the species R. laguerreae was described later $[9,25]$. Strains AMPS05 and AMPS34 belong to a cluster containing strains isolated from Vicia sativa in Asia and Europe [21,22,26]. Finally, the strain AMPS22 was closely related to a strain isolated by Rashid et al. [25] from nodules of L. culinaris in Germany (Figure 3). It is remarkable that, from the strains isolated from P. sativum nodules whose $r$ rs sequences were almost identical to that of the strain AMPS22, only the strain BIHB1132 belongs to R. laguerreae. The strains A1 and JKLM13E, were related to the type strains of $R$. ruizarguesonis and $R$. indicum, respectively, and the strain BIHB1160 formed and independent lineage (Figure 3). In the case of the strains carrying the IVS and whose rrs gene sequences were identical, we also found important divergences for $r e c A$ and atpD genes, particularly in the case of the strain JHI2449, which showed $96.3 \%$ and $98.2 \%$ similarity, respectively, with respect to the type strain of $R$. laguerreae, these values being within the limit for species differentiation. Nevertheless, we also found the opposite case, since strains with some differences in the rrs gene, such as the strain AMPS17, were closely related to the type strain of $R$. laguerreae in the $\operatorname{rec} A$ and $\operatorname{atp} D$ gene analysis. These results confirmed again that the rrs gene is not a suitable marker for differentiation of closely related species, other core protein-coding genes being more adequate for species delineation.

Table 1. Characteristics of selected strains isolated from Pisum sativum root nodules.

\begin{tabular}{|c|c|c|c|c|c|c|c|c|c|}
\hline Strain & $\begin{array}{l}\text { RAPD } \\
\text { Group }\end{array}$ & $\begin{array}{c}\text { recA Gene } \\
\text { * Similarity } \\
(\%)\end{array}$ & $\begin{array}{c}\text { atpD Gene } \\
\text { * Similarity } \\
(\%)\end{array}$ & $\begin{array}{l}\text { Cellulases } \\
\text { Production }\end{array}$ & $\begin{array}{l}\text { Cellulose } \\
\text { Production }\end{array}$ & $\frac{\text { AHL }}{\text { Production }} \S$ & $\begin{array}{c}\text { IAA } \\
(\mathrm{mg} / \mathrm{L})\end{array}$ & $\begin{array}{l}\text { Siderophore } \\
\text { Production }\end{array}$ & $\begin{array}{c}\text { Phosphate } \\
\text { Solubilization } f\end{array}$ \\
\hline AMPS04 & VI & 96.7 & 100 & $\mathrm{w}$ & $\mathrm{w}$ & $1: 125$ & 0.082 & 4 & 0.00 \\
\hline AMPS17 & IV & 99.8 & 100 & w & + & $1: 3125$ & 0.040 & 4 & 0.00 \\
\hline AMPS22 & III & 96.5 & 98.1 & + & + & $1: 3125$ & 0.023 & 1 & 0.00 \\
\hline AMPS23 & $\mathrm{V}$ & 96.7 & 100 & + & + & $1: 25$ & 0.023 & 1 & 1.33 \\
\hline
\end{tabular}

*: this value was calculated with respect to the type strain of R. laguerreae $\mathrm{FB}^{206^{\mathrm{T}}}$. w: weakly positive, +: positive.

s: last dilution in which AHL was detected (following the methodology of Trovato et al. [27]). ${ }^{\ngtr}:$ halo size (mm) around colony. ${ }^{f}$ : ratio between the diameter of the halo around the colony with respect to colony size [28]. 


\subsection{Analysis of the nodC Gene}

The nodulation genes are responsible for the legume nodule formation, and among them, the nodC gene is the most common phylogenetic marker to define rhizobial symbiovars $[29,30]$. The symbiovar concept (formerly biovar) is related to both the rhizobial host range and the legume promiscuity degree and hence to the old cross-inoculation group concept [30]. In this way, a promiscuous legume can be nodulated by various symbiovars, and a restrictive legume can only be nodulated by one symbiovar [30]. The legumes from the Vicia cross-inoculation group, which includes Vicia, Pisum, Lens, and Lathyrus, are considered restrictive hosts for nodulation [31], nodulated by strains of the symbiovar viciae [32]. It is remarkable that a single species can contain several symbiovars; the first reported case was the species R. leguminosarum, which contains three symbiovars, two of which nodulate restrictive hosts such as Vicia, Pisum, Lens, Lathyrus (viciae), and Trifolium (trifolii) and one of which nodulates the very promiscuous host Phaseolus (phaseoli) [32]. These three symbiovars are clearly separated through nodC gene analysis [33,34], and for this reason it has been analyzed in many strains isolated from nodules of legumes from the Vicia cross-inoculation group in different geographical locations (Figure 4).

The analysis of the nodC gene showed that, as expected, the closest related strains to those from this study are those of the symbiovar viciae, with similarity values higher than $92 \%$. Nevertheless, the phylogenetic analysis of the nodC gene showed that these strains belong to two different clusters (Figure 4). Strains AMPS04, AMPS34, AMPS05, and AMPS22 belong to a cluster that encompasses strains isolated from nodules of Pisum, Vicia, and Lens in several countries in Europe and Africa, and strains AMPS17 and AMPS23 belong to a wide cluster encompassing strains nodulating the same legumes in different countries in Europe, America, Asia, and Africa. These results confirmed the existence of an important genetic variability within the symbiovar viciae worldwide, with similarity values lower than $95 \%$ in the nodC gene. This value is within the range of internal similarity of most defined symbiovars, but it is lower than the values reported for the strains of the novel symbiovar aegeanense recently described within the genus Ensifer, which showed more than 95\% similarity with respect to the symbiovar fredii [35].

\subsection{Biofilm Formation and Quorum Sensing}

Cellulases and cellulose produced by Rhizobium strains are involved in plant colonization and biofilm formation in legume roots [36], and they are produced by several Rhizobium species that are able to form biofilms [36], including some strains from R. laguerreae isolated from P. vulgaris nodules [37]. In agreement with these results, all strains analyzed in this study produced cellulases and cellulose (Table 1, Figure 5A). They were able to form biofilms on abiotic surfaces, and an increase in the biofilm formation over time was found in all selected strains, with significant differences between the biofilm formation after 24 and $48 \mathrm{~h}$, except in the strain AMPS23. Significant differences were also found after $72 \mathrm{~h}$ in strains AMPS04, AMPS05, AMPS23, and AMPS34 (Figure 5(Ba)). The strain AMPS05 exhibits the highest biofilm formation at $72 \mathrm{~h}$ and the strain AMPS22 at 24 and $48 \mathrm{~h}$ (Figure 5(Bb)). These results are in agreement with those found for Rhizobium strains nodulating clover [36] or common bean [37].

Rhizobial strains from populations formed on the legume roots communicate among them through signaling systems based on the quorum sensing compounds of the $\mathrm{N}$-acyl-homoserine lactone groups (AHLs), which stimulate the genetic exchange among bacteria in the legume rhizosphere and play a direct role in the legume nodulation process $[38,39]$. Symbiotic rhizobia have different AHL-based quorum sensing systems, and within the genus Rhizobium, they have been studied in R. etli and R. leguminosarum [39]. In this study, we detected quorum sensing signals in culture supernatants of all strains, although some differences in active molecule production were found (Table 1, Figure 5C). Strains AMPS17 and AMPS22 were able to produce the highest estimated concentration of AHL, followed by strains AMPS04 and AMPS05, strains AMPS23 and AMPS34 being those producing the lowest AHL concentrations (Figure 5C). Differences in the production of AHL have been found in different strains and symbiovars of R. leguminosarum [40], but this is the first work in which the AHL 
production is compared in different Rhizobium strains isolated from legume nodules using the micro method described in the work of Trovato et al. [27].

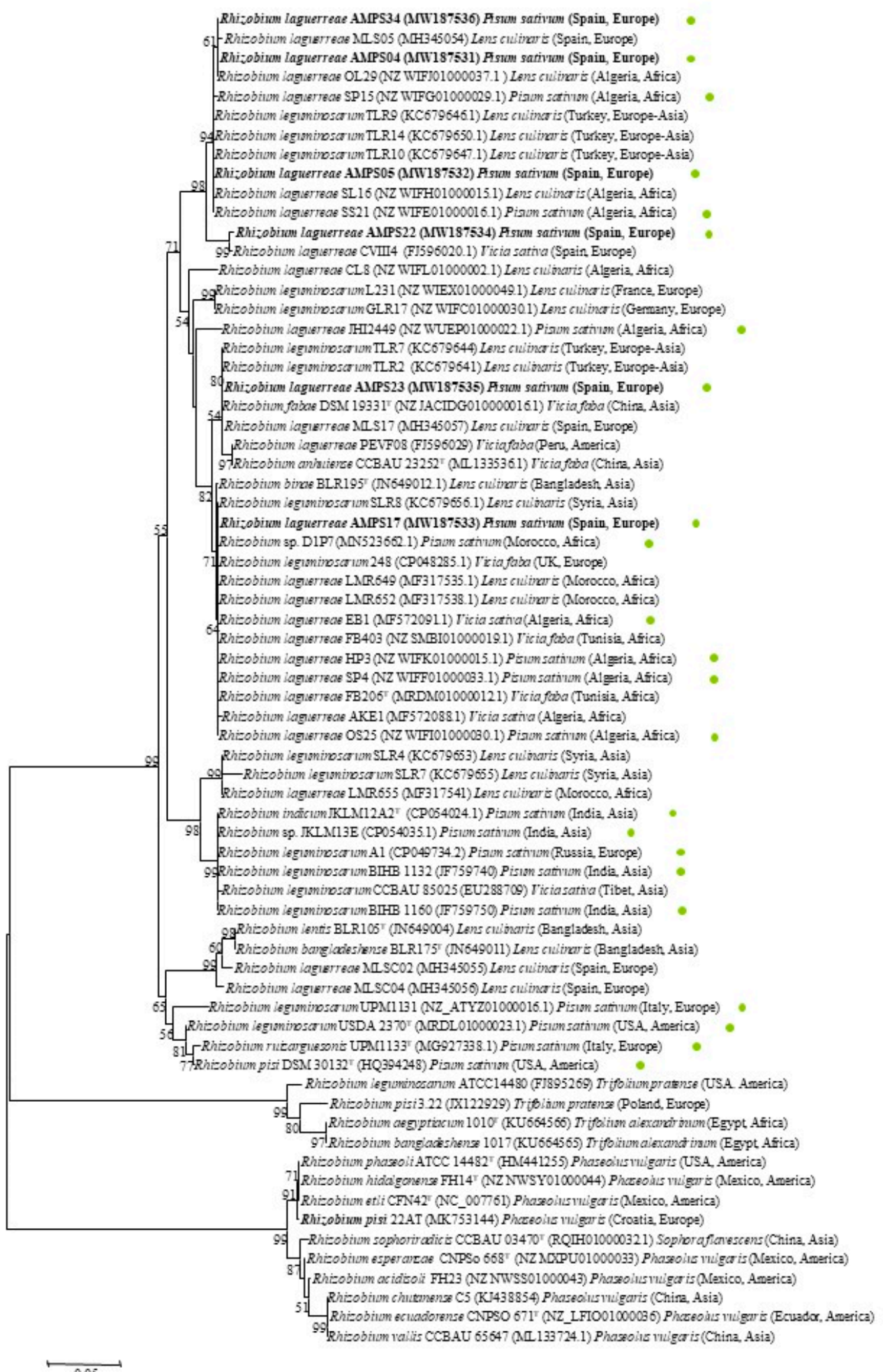

Figure 4. Neighbor-joining unrooted phylogenetic tree based on nodC gene sequences (370 nt) showing the position of representative strains from each group within the symbiovars viciae and phaseoli. Bootstrap values calculated for 1000 replications are indicated. Bar: 5 nt substitution per $100 \mathrm{nt}$. Filled green circles indicated the strains isolated from Pisum sativum worldwide. 
A

(a)

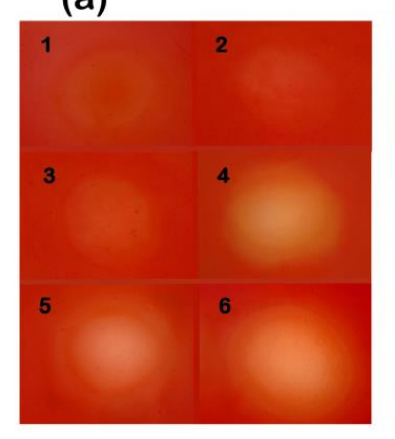

(b)

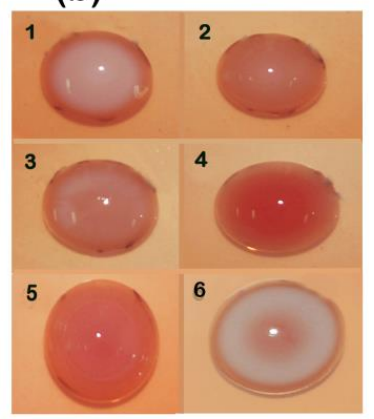

C

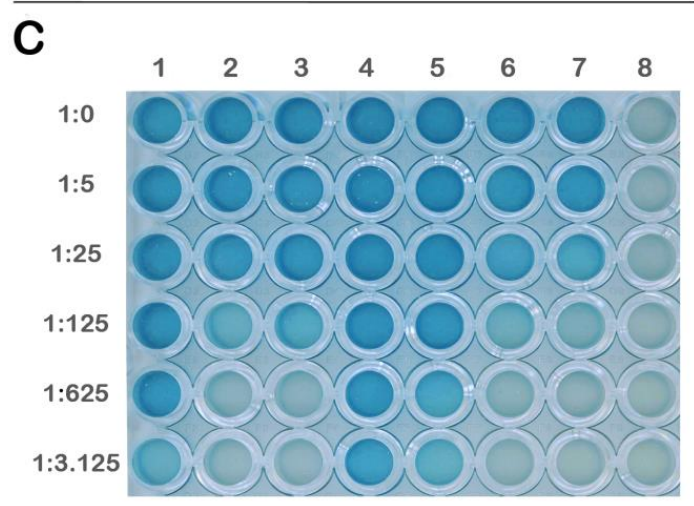

B

(a)

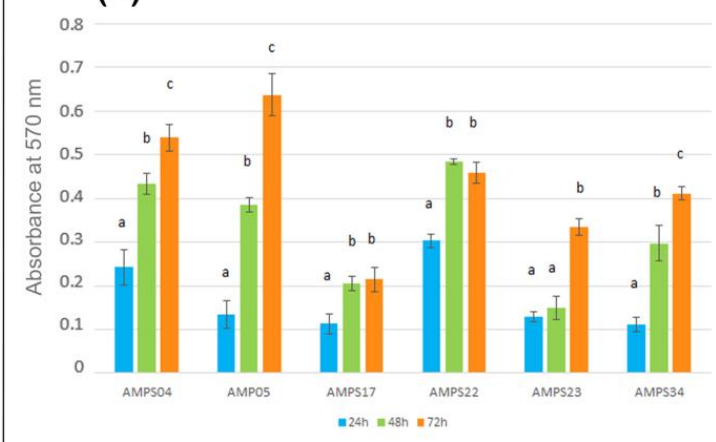

(b)

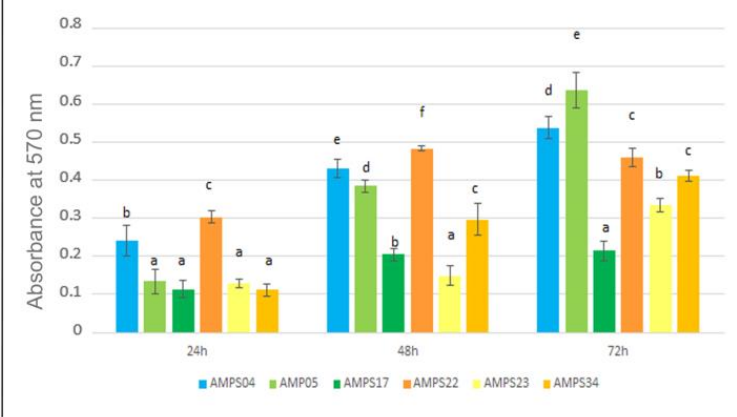

Figure 5. (Panel A): Cellulase production on CMC (carboxy-methyl-cellulose) (a) and cellulose-like polysaccharides production on plates containing Congo Red (b) by the strains: 1. AMPS04, 2. AMPS05, 3. AMPS17, 4. AMPS22, 5. AMPS23, 6. AMPS34. (Panel B): Absorbance values at $570 \mathrm{~nm}$ OD of CV-stained biofilms formed on PVC plates by the analyzed strains at different incubation times (a) and evolution along the time of these values for each strain (b). Each graph bar represents the average of at least eight wells. Error bars indicate the standard deviation. Values followed by the same letter in each treatment are not significantly different from each other at $p=0.05$ according to Fisher's Protected LSD test (least significant differences). (Panel C): Results of the bioassay production of quorum sensing molecules after serial dilutions of supernatants from liquid cultures of strains dispensed over a semisolid culture of the bioreporter strain Agrobacterium tumefaciens NTL4: 1. Positive control with $10 \mathrm{ng} / \mathrm{mL}$ of OHL (N-3-octanoyl homoserine lactone), 2. AMPS04, 3. AMPS05, 4. AMPS17, 5. AMPS20, 6. AMPS22, 7. AMPS34, and 8. Negative control with distilled water.

\subsection{In Vitro Plant Growth Promotion Mechanisms}

The ability to fix nitrogen in symbiosis with legumes was the first plant growth promotion mechanism studied in members of the genus Rhizobium [41], but other mechanisms have been more recently reported, such as the ability to solubilize phosphate, to synthesize indole acetic acid, or to produce siderophores [42]. In this work, we analyzed these mechanisms in selected strains from each RAPD group showing that all of them produced IAA and siderophores, but only two of them were able to solubilize phosphate (Table 1). Strains AMPS04, AMPS05, and AMPS34 produced higher IAA amounts, which were similar or higher than those reported for other Rhizobium strains [37,43,44]. Concerning siderophore production, the strain AMPS34 produced the halo with the largest radius in the CAS medium, but in general the results were similar to those previously found for other Rhizobium strains $[37,43,44]$. The ability to solubilize phosphate was found in only two strains, AMPS23 and AMPS34 (Table 1), which agrees with previous works where this mechanism was less frequently found in Rhizobium strains [43]. All these results are in agreement with those obtained for 
other Rhizobium strains [43,44], including two R. laguerreae strains isolated from common bean and clover nodules [37,45].

\subsection{Effectiveness on Pea Plants}

The effectiveness of rhizobia-legume symbiosis is directly related to the symbiotic nitrogen fixation process carried out by the rhizobia inside the nodules [46]. Therefore, the nodulation ability is also directly related to the effectiveness of rhizobial strains, since nodule formation and growth are regulated in response to the $\mathrm{N}$ present in the legume phloem and/or in the soil $[47,48]$. Moreover, as previously indicated, symbiotic nitrogen fixation was the first studied mechanism of plant growth promotion; therefore, classically, the parameters analyzed to determine the effectiveness of rhizobial strains have been the number of nodules, the $\mathrm{N}$ content, and the fresh and dry matter of the legume shoots. The obtained results for these parameters in P. sativum plants inoculated with selected strains from this study are displayed in Table 2. They show that, as expected, all strains were able to nodulate $P$. sativum, and significant differences in the number of nodules per plant were found between the strain AMPS04 and the type strain of R. pisi. All inoculation treatments yielded P. sativum plants with significantly higher fresh and dry weights than those from the uninoculated control without nitrogen addition. Both parameters were significantly lower in all treatments, including the positive control plants inoculated with the type strain of $R$. pisi, with respect to the positive noninoculated control plants watered with a nutrient solution containing $0.5 \mathrm{~g} / \mathrm{L}$ of ammonium nitrate as $\mathrm{N}$ source. Among the inoculation treatments, those performed with the type strain of R. pisi and with the strain AMPS34 yielded higher values for fresh and dry weights. Both values were not significantly different between these treatments and with respect to those corresponding to the inoculation with the strains AMPS05 and AMPS17. Concerning the percentage of fixed N, all treatments presented significant differences with respect to the uninoculated control without added $\mathrm{N}$, and no significant differences were found among the remaining treatments. The total $\mathrm{N}$ content per plant showed the same behavior as that of the shoot dry weight (Table 2). These results imply that, although some strains were more effective than others, in general the strains of $R$. laguerreae sv. viciae showed high symbiotic efficiency in pea plants, with no significant differences between plants inoculated with the type strain of R. pisi and those inoculated with the strain AMPS34. In this last case, the percentage of fixed N per plant was only $2.5 \%$ lower than in the plants watered with a nutrient solution containing $\mathrm{N}$ sources. These results imply that $R$. laguerreae strains established highly effective symbiosis with $P$. sativum and can be used as inoculants for this legume.

Table 2. Effectiveness of selected strains on Pisum sativum plants.

\begin{tabular}{|c|c|c|c|c|c|}
\hline Treatment & $\begin{array}{l}\text { Nodules/Plant } \\
\quad( \pm \text { S.E. })\end{array}$ & $\begin{array}{l}\text { Shoot Fresh Weight } \\
\text { (g)/Plant }( \pm \text { S.E.) }\end{array}$ & $\begin{array}{l}\text { Shoot Dry Weight } \\
\text { (g)/Plant ( } \pm \text { S.E.) }\end{array}$ & $\begin{array}{l}\text { N (\%) } \\
( \pm \text { S.E. })\end{array}$ & $\begin{array}{c}\text { Total N (mg)/Plant } \\
( \pm \text { S.E.) }\end{array}$ \\
\hline $\begin{array}{l}\text { Uninoculated plants } \\
\text { (without N) }\end{array}$ & & $1.19( \pm 0.02)^{\mathrm{a}}$ & $0.21( \pm 0.02)^{a}$ & $2.77( \pm 0.08)^{\mathrm{a}}$ & $5.72( \pm 0.13)^{a}$ \\
\hline $\begin{array}{l}\text { Uninoculated plants } \\
\text { (with } \mathrm{N}) *\end{array}$ & & $2.81( \pm 0.03)^{f}$ & $0.45( \pm 0.03)^{f}$ & $4.28( \pm 0.12)^{b c}$ & $19.22( \pm 0.26)^{f}$ \\
\hline R. pisi DSM $30132^{\mathrm{T}}$ & $52( \pm 2.44)^{\mathrm{a}}$ & $2.74( \pm 0.04)^{\mathrm{e}}$ & $0.42( \pm 0.03) \mathrm{de}$ & $4.15( \pm 0.09) b c$ & $17.49( \pm 0.29)^{\mathrm{e}}$ \\
\hline AMPS17 & $53( \pm 2.55)^{\mathrm{a}}$ & $2.66( \pm 0.03)$ cde & $0.40( \pm 0.03)^{d}$ & $4.13( \pm 0.07) b c$ & $16.70( \pm 0.26)^{d}$ \\
\hline AMPS22 & $55( \pm 2.14)^{a b}$ & $2.55( \pm 0.03) b c$ & $0.36( \pm 0.05)^{b}$ & $4.08( \pm 0.05)^{b}$ & $14.72( \pm 0.28)^{b}$ \\
\hline AMPS23 & $52( \pm 1.86)^{a}$ & $2.65( \pm 0.02) c d$ & $0.39( \pm 0.03) \mathrm{cd}$ & $4.14( \pm 0.11) b c$ & $15.94( \pm 0.27)^{\mathrm{cd}}$ \\
\hline AMPS34 & $51( \pm 1.79)^{a}$ & $2.70( \pm 0.04)^{\mathrm{e}}$ & $0.42( \pm 0.04)$ de & $4.17( \pm 0.08)^{b c}$ & $17.42( \pm 0.28)$ de \\
\hline
\end{tabular}

Values followed by the same letter in each treatment are not significantly different from each other at $p=0.05$ according to Fisher's protected LSD test (least significant differences). S.E. = standard error. ${ }^{*}$ Plants were watered with Rigaud and Pupo solution [49] containing $0.5 \mathrm{~g} / \mathrm{L}$ of ammonium nitrate. 


\section{Materials and Methods}

\subsection{Diversity Analysis of Strains by RAPD Fingerprinting}

The strains were isolated in a previous work from effective nodules (pink colour) of P. sativum plants at the flowering stage in Aldea de San Miguel $\left(41^{\circ} 27^{\prime} 37^{\prime \prime} \mathrm{N} 4^{\circ} 37^{\prime} 01^{\prime \prime} \mathrm{W}\right)$, located in Valladolid province (Spain), where this legume is commonly cultivated [12].

The genetic diversity of isolated strains was assessed by RAPD fingerprinting performed as previously described [50] with the primer M13 (5'- GAGGGTGGCGGTTCT- $3^{\prime}$ ) and the Dream-Taq ${ }^{\text {TM }}$ DNA Green PCR Master Mix (Fisher Scientific, Waltham, MA, USA). PCR conditions were the following: preheating at $95^{\circ} \mathrm{C}$ for $9 \mathrm{~min}, 35$ cycles of denaturing at $95^{\circ} \mathrm{C}$ for $1 \mathrm{~min}$, annealing at $45^{\circ} \mathrm{C}$ for $1 \mathrm{~min}$, and extension at $75^{\circ} \mathrm{C}$ for $2 \mathrm{~min}$, with a final extension at $72{ }^{\circ} \mathrm{C}$ for $7 \mathrm{~min}$. Aliquots of $17 \mu \mathrm{L}$ of each PCR product were electrophoresed on 1.5\% (w/v) agarose gel in TBE buffer (100 mM Tris, $83 \mathrm{mM}$ boric acid, $1 \mathrm{mM}$ EDTA, $\mathrm{pH} 8.5$ ) at $6 \mathrm{~V} / \mathrm{cm}$. The gels were stained in a solution containing $0.5 \mathrm{mg} / \mathrm{L}$ ethidium bromide, and photographed under UV light. Standard VI (Roche, Basilea, Switzerland) was used as a size marker. A dendrogram was constructed based on the matrix generated using the UPGMA method and Pearson's coefficient with Bionumerics version 4.0 (Applied Maths, Austin, TX, USA).

\subsection{Gene Sequencing and Analysis}

The amplification and sequencing of $r r s, \operatorname{rec} A, \operatorname{atp} D$, and nodC genes were carried out as indicated by Carro et al. [51], Gaunt et al. [23], and Laguerre et al. [33], respectively. These genes were sequenced at the Sequencing DNA Service (NUCLEUS) from Salamanca University (Salamanca, Spain). The obtained sequences were compared with those from GenBank using the BLASTN program [52]. Sequences were aligned using the ClustalX software [53]. The distances were calculated according to Kimura's two-parameter model [54]. Phylogenetic trees were inferred using the neighbor-joining (NJ) analysis [55]. MEGA7 software [56] was used for all these analyses.

\subsection{Quorum Sensing Signals and Biofilm Production}

For the evaluation of the production of quorum sensing signals, strains were grown in $20 \mathrm{~mL}$ of YMB medium [57] for $48 \mathrm{~h}$. Then $2 \mathrm{~mL}$ were transferred to $18 \mathrm{~mL}$ of YMB medium and were incubated for $24 \mathrm{~h}$ at $28^{\circ} \mathrm{C}$. The cultures were centrifuged $4 \mathrm{~min}$ at $4500 \times \mathrm{g}$, and the supernatants were filtered with a $0.22 \mu \mathrm{m}$ pore filter. The strain Agrobacterium tumefaciens NTL4 (pZRL4) was employed as a reporter of AHL (acylated homoserine lactone) quorum sensing molecules. This strain was inoculated in $20 \mathrm{~mL}$ of liquid $\mathrm{AB}$ medium [58] supplemented with $30 \mu \mathrm{g} / \mathrm{mL}$ gentamycin and was incubated for $24 \mathrm{~h}$ at $28^{\circ} \mathrm{C}$. Afterwards, $10 \mathrm{~mL}$ of this culture were mixed with $\mathrm{AB}$ medium with agarose $(1 \% \mathrm{w} / \mathrm{v})$ at $43{ }^{\circ} \mathrm{C}$ and $150 \mu \mathrm{L}$ of $\mathrm{X}$-gal (5-bromo-4-chloro-3-indolyl-beta-D-galactopyranoside) stock solution for a final concentration of $60 \mu \mathrm{g} / \mathrm{mL}$. Aliquots of $200 \mu \mathrm{L}$ of this suspension were dispensed in each well of a 96-well microtiter plate. Upon medium solidification, $10 \mu \mathrm{L}$ of a solution containing $10 \mathrm{ng} / \mu \mathrm{L}$ of OHL (N-Octanoyl-DL-homoserine lactone, Sigma Aldrich Co., St. Luis, MO, USA), filtered supernatants, and their serial dilutions were added. OHL was chosen as the AHL positive control. After $24 \mathrm{~h}$ of incubation, the digital image was acquired by an HP Scanjet 8200 flatbed scanner.

The ability of strains to form biofilms on abiotic surfaces was measured using the microtiter plate assay crystal violet post-staining as described by Robledo et al. [36]. The strains were grown in the minimal medium until reaching a value of 2.0 at $600 \mathrm{~nm}$ OD (ca. $1 \times 10^{7}$ cells $/ \mathrm{mL}$ ). A decimal dilution was used for subsequent biofilm formation measurements [36]. Biofilm data were treated with one-way ANOVA and the Fisher's post hoc test at a $p$ value $\leq 0.05$, using StatView 5.0 (Abacus Corporation, Berkeley, CA, USA). Data were analyzed by one-way ANOVA, and mean values were compared with Fisher's protected LSD test (least significant differences) ( $p \leq 0.05$ ).

Cellulase production was tested on CMC double-layer plates as was previously described [59] and after 7 days the presence/absence of hydrolysis halos was recorded. Cellulose detection assay was carried out as described by Robledo et al. [36]. 


\subsection{In Vitro Plant Growth Promoting Mechanisms}

The solubilization of insoluble phosphate was analyzed on YED-P plates containing $2 \% \mathrm{CaHPO}_{4}$ or $\mathrm{Ca}_{3}\left(\mathrm{HPO}_{4}\right)_{2}$, which were incubated for 15 days at $28^{\circ} \mathrm{C}$ [60]. Phosphate-solubilization effectiveness was calculated as the ratio between the halos around the colony with respect to colony size [28]. Siderophore production was evaluated in M9-CAS-AGAR [61] modified with the addition of a cationic solvent, HDTMA, which stabilizes the Fe-CAS complex and gives the medium its characteristic color [62]. Indole acetic acid production was evaluated in JMM medium [63] supplemented with $107 \mathrm{mg} / \mathrm{L}$ of tryptophan. After 7 days of incubation, the supernatants were recovered by centrifugation at $5000 \times g$ and filtered using $0.22 \mu \mathrm{m}$ Millipore filters (Millipore Co., Burlington, MA, USA). Afterwards, $1 \mathrm{~mL}$ of Salkowsky reagent was added to $2 \mathrm{~mL}$ of supernatant, and the red color formed was measured by spectrophotometry at $550 \mathrm{~nm}$ using an ATI Unicam 8625 Spectrometer (Mattson, Madison, WI, USA) [64].

\subsection{Effectiveness Assays in Pisum sativum}

For these assays, seeds of Pisum sativum var. "Rondo" were surface-sterilized with 5\% sodium hypochlorite for $25 \mathrm{~min}$. The sterilized seeds were germinated in sterile vermiculite and then inoculated with $1 \mathrm{~mL}$ per plant of a suspension containing approximately $1 \times 10^{8} \mathrm{CFU} / \mathrm{mL}$ of each strain. Cells were obtained from cultures on YMA plates incubated for 5 days at $28^{\circ} \mathrm{C}$ and were suspended in sterile water. The inoculated plants were placed in a plant growth chamber with mixed incandescent and fluorescent lighting (400 microeinsteins $\mathrm{m}^{-2} \mathrm{~s}^{-1} ; 400-700 \mathrm{~nm}$ ), programmed for a $16 \mathrm{~h}$ photoperiod, day-night cycle, with a constant temperature varying from 25 to $27^{\circ} \mathrm{C}$, and $50-60 \%$ relative humidity. Plants were watered with nitrogen-free Rigaud and Puppo [49] nutrient solution. A positive control was watered weekly with the same solution, with $0.5 \mathrm{~g} / \mathrm{L}$ ammonium nitrate. Plants inoculated with the type strain of Rhizobium pisi DSM $30132^{\mathrm{T}}$ were included as a reference. Four weeks after inoculation, plants were harvested, the number of nodules was counted, the fresh and dry weight, and the nitrogen content of the aerial parts of plants were measured. This last analysis was performed in the Ionomic Service from CEBAS-CSIC (Murcia, Spain). Data were analyzed by one-way ANOVA, and mean values were compared by Fisher's protected LSD test (least significant differences) $(p \leq 0.05)$.

\section{Conclusions}

Collectively, the results of this study showed the following: (i) although several type strains of different species from the group of $R$. leguminosarum have identical rrs gene sequences, some differences have been found in this gene with respect to other strains of these species, including the presence of an insert (IVS) of $75 \mathrm{bp}$ at the beginning of the rrs gene. (ii) Strains carrying identical IVS in their rrs genes were isolated from nodules of Pisum, Lens, and Vicia in different countries from Europe and Asia. (iii) All these strains belong to the species R. laguerreae according to the results of the $r e c A$ and $a t p D$ gene analysis, which suggests that several of these strains are currently misnamed in GenBank. (iv) All strains analyzed in this study have been identified as R. laguerreae after rec $A$ and atpD gene analysis, and they belong to different clusters within this species, whose complexity was confirmed in this work. (v) Further studies based on whole genome analysis are necessary to establish cut-off values for genospecies or subspecies differentiation as well as to propose the correction of the misnamed strains. (vi) R. laguerreae is widely distributed in nodules of Pisum, Vicia, and Lens, three grain legumes cultivated for human and animal feeding worldwide, but some strains assigned to this species presented similarity values in their $\operatorname{rec} A$ and $\operatorname{atp} D$ genes lower than those currently accepted for species differentiation. (vii) The analysis of the nodC gene showed that all strains analyzed in this study belong to the symbiovar viciae, which is distributed worldwide in the nodules of legumes from Pisum, Lens, and Vicia. (viii) This symbiovar is phylogenetically very complex and currently encompasses strains showing nodC gene similarity values lower than those presented by recently described symbiovars, evidencing that a consensus is necessary to establish cut-off values for symbiovar delineation. (ix) All strains from this study produced molecules involved in plant colonization and 
quorum sensing, such as cellulose, cellulases, and N-acyl-homoserine lactones. (x) These strains also produced IAA and siderophores, but the phosphate solubilization of tricalcium phosphate was only observed for two strains. (xi) All strains were effective on pea plants, with the strain AMPS34 as the most efficient, without significant differences with respect to the type strain of $R$. pisi used as a reference in this study. (xii) Taking into account the wide distribution of $R$. laguerreae sv. viciae strains in different countries and continents in P. sativum nodules and their high effectiveness in symbiosis with this legume, $R$. laguerreae sv. viciae is a promising candidate for the biofertilization of peas worldwide.

Author Contributions: Conceptualization, A.S., R.R. and E.V.; methodology, A.S. and E.V.; formal analysis, L.C., R.R. and E.V.; investigation, J.D.F.-F., L.C. and E.C.-C.; resources, A.S., R.R., and E.V.; data curation, J.D.F.-F. and E.V.; writing—original draft preparation, J.D.F.-F., L.C., E.C.-C. and E.V.; writing-review and editing, J.D.F.-F., A.S., R.R. and E.V.; funding acquisition, E.V. All authors have read and agreed to the published version of the manuscript.

Funding: This work was supported by MICINN (Ministry of Science and Innovation, Spanish Central Government) Grant AGL2013-48098-P to EV.

Acknowledgments: The authors also thank the Excellence Unit of the Spanish-Portuguese Institute for Agricultural Research (CIALE) (CLU-2018-04) for the provision of research facilities. JDFF is currently a recipient of a postdoctoral Marie Skłodowska-Curie fellowship No 101003373.

Conflicts of Interest: The authors declare that there is no conflict of interest.

\section{References}

1. Dahl, W.J.; Foster, L.M.; Tyler, R.T. Review of the health benefits of peas (Pisum sativum L.). Br. J. Nutr. 2012, 108, S3-S10. [CrossRef] [PubMed]

2. Santos, C.S.; Carbas, B.; Castanho, A.; Vasconcelos, M.W.; Vaz Patto, M.C.; Domoney, C.; Brites, C. Variation in pea (Pisum sativum L.) seed quality traits defined by physicochemical functional properties. Foods 2019, 8, 570. [CrossRef] [PubMed]

3. Spanish Ministry of Agriculture, Fishing and Food (Ministerio de Agricultura, Pesca y Alimentación). Anuario de Estadística 2019. Available online: https://www.mapa.gob.es/es/estadistica/temas/publicaciones/ anuario-de-estadistica/2019/default.aspx (accessed on 14 July 2020).

4. Frank, B. Ueber die Pilzsymbiose der Leguminosen. Ber. Deutsch. Bot. Ges. 1889, 7, 332-346.

5. Ramírez-Bahena, M.H.; García-Fraile, P.; Peix, A.; Valverde, A.; Rivas, R.; Igual, J.M.; Mateos, P.F.; Martínez-Molina, E.; Velázquez, E. Revision of the taxonomic status of the species Rhizobium leguminosarum (Frank 1879) Frank 1889AL, Rhizobium phaseoli Dangeard 1926AL and Rhizobium trifolii Dangeard 1926AL. $R$. trifolii is a later synonym of $R$. leguminosarum. Reclassification of the strain R. leguminosarum DSM 30132 (=NCIMB 11478) as Rhizobium pisi sp. nov. Int. J. Syst. Evol. Microbiol. 2008, 58, 2484-2490. [CrossRef]

6. Rahi, P.; Giram, P.; Chaudhari, D.; di Cenzo, G.C.; Kiran, S.; Khullar, A.; Chandel, M.; Gawari, S.; Mohan, A.; Chavan, S.; et al. Rhizobium indicum sp. nov., isolated from root nodules of pea (Pisum sativum) cultivated in the Indian trans-Himalayas. Syst. Appl. Microbiol. 2020, 43, 126127. [CrossRef]

7. Jorrin, B.; Palacios, J.M.; Peix, A.; Imperial, J. Rhizobium ruizarguesonis sp. nov., isolated from nodules of Pisum sativum L. Syst. Appl. Microbiol. 2020, 43, 126090. [CrossRef]

8. Zhang, Y.J.; Zheng, W.T.; Everall, I.; Young, J.P.W.; Zhang, X.X.; Tian, C.F.; Sui, X.H.; Wang, E.T.; Chen, W.X. Rhizobium anhuiense sp. nov., isolated from effective nodules of Vicia faba and Pisum sativum. Int. J. Syst. Evol. Microbiol. 2015, 65, 2960-2967. [CrossRef]

9. Rahi, P.; Kapoor, R.; Young, J.P.; Gulati, A. A genetic discontinuity in root-nodulating bacteria of cultivated pea in the Indian trans-Himalayas. Mol. Ecol. 2012, 21, 145-159. [CrossRef]

10. Ruiz-Díez, B.; Fajardo, S.; Felipe, M.R.; Fernández-Pascual, M. Characterization of rhizobia from legumes of agronomic interest grown in semi-arid areas of Central Spain relates genetic differences to soil properties. J. Basic Microbiol. 2012, 52, 66-78. [CrossRef]

11. Gurkanli, C.T.; Ozkoc, I.; Gunduz, I. Genetic diversity of Vicia faba L. and Pisum sativum L. nodulating rhizobia in the central Black Sea region of Turkey. Ann. Microbiol. 2014, 64, 99-112. [CrossRef] 
12. Martínez-Molina, E.; Sánchez Juanes, F.; Carro, L.; Flores-Félix, J.D.; Martínez-Hidalgo, P.; Cerda Castillo, E.; González Buitrago, J.M.; Velázquez, E. Identification of rhizobial strains nodulating Pisum sativum in Northern Spain soils by MALDI-TOF MS (Matrix-Assisted Laser Desorption Ionization Time-of-Flight Mass Spectrometry) analysis. In Biological Nitrogen Fixation and Beneficial Plant-Microbe Interaction; González-Andrés, F., James, E., Eds.; Springer: Cham, Switzerland, 2015; pp. 37-44. [CrossRef]

13. Blažinkov, M.; Uher, D.; Romanjek Fajdetić, N.; Japundžić-Palenkić, B.; Sikora, S. Biodiversity and symbiotic efficiency of indigenous rhizobia nodulating field pea. J. Cent. Eur. Agric. 2020, 21, 292-299. [CrossRef]

14. Boivin, S.; Lahmidi, N.A.; Sherlock, D.; Bonhomme, M.; Dijon, D.; Heulin-Gotty, K.; Le-Queré, A.; Pervent, M.; Tauzin, M.; Carlsson, G.; et al. Host-specific competitiveness to form nodules in Rhizobium leguminosarum symbiovar viciae. New Phytol. 2020, 226, 555-568. [CrossRef] [PubMed]

15. Missbah El-Idrissi, M.; Lamin, H.; Bouhnik, O.; Lamrabet, M.; Alami, S.; Jabrone, Y.; Bennis, M.; Bedmar, E.J.; Abdelmoumen, H. Characterization of Pisum sativum and Vicia faba microsymbionts in Morocco and definition of symbiovar viciae in Rhizobium acidisoli. Syst. Appl. Microbiol. 2020, 43, 126084. [CrossRef] [PubMed]

16. Moschetti, G.; Peluso, A.L.; Protopapa, A.; Anastasio, M.; Pepe, O.; Defez, R. Use of nodulation pattern, stress tolerance, nodC gene amplification, RAPD-PCR and RFLP-16S rDNA analysis to discriminate genotypes of Rhizobium leguminosarum biovar viciae. Syst. Appl. Microbiol. 2005, 28, 619-631. [CrossRef]

17. Santillana, N.; Ramírez-Bahena, M.H.; García-Fraile, P.; Velázquez, E.; Zúñiga, D. Phylogenetic diversity based on $r r s$, atpD, recA genes and 16S-23S intergenic sequence analyses of rhizobial strains isolated from Vicia faba and Pisum sativum in Peru. Arch. Microbiol. 2008, 189, 239-247. [CrossRef]

18. Alvarez-Martínez, E.R.; Valverde, A.; Ramírez-Bahena, M.H.; García-Fraile, P.; Tejedor, C.; Mateos, P.F.; Santillana, N.; Zúñiga, D.; Peix, A.; Velázquez, E. The analysis of core and symbiotic genes of rhizobia nodulating Vicia from different continents reveals their common phylogenetic origin and suggests the distribution of Rhizobium leguminosarum strains together with Vicia seeds. Arch. Microbiol. 2009, 191, 659-668. [CrossRef]

19. Van Cauwenberghe, J.; Verstraete, B.; Lemaire, B.; Lievens, B.; Michiels, J.; Honnay, O. Population structure of root nodulating Rhizobium leguminosarum in Vicia cracca populations at local to regional geographic scales. Syst. Appl. Microbiol. 2014, 37, 613-621. [CrossRef]

20. Villadas, P.J.; Lasa, A.V.; Martínez-Hidalgo, P.; Flores-Félix, J.D.; Martínez-Molina, E.; Toro, N.; Velázquez, E.; Fernández-López, M. Analysis of rhizobial endosymbionts of Vicia, Lathyrus and Trifolium species used to maintain mountain firewalls in Sierra Nevada National Park (South Spain). Syst. Appl. Microbiol. 2017, 40, 92-101. [CrossRef]

21. Flores-Félix, J.D.; Sánchez-Juanes, F.; García-Fraile, P.; Valverde, A.; Mateos, P.F.; Gónzalez-Buitrago, J.M.; Velázquez, E.; Rivas, R. Phaseolus vulgaris is nodulated by the symbiovar viciae of several genospecies of Rhizobium laguerreae complex in a Spanish region where Lens culinaris is the traditionally cultivated legume. Syst. Appl. Microbiol. 2019, 42, 240-247. [CrossRef]

22. Saïdi, S.; Ramírez-Bahena, M.H.; Santillana, N.; Zúñiga, D.; Álvarez-Martínez, E.; Peix, A.; Mhamdi, R.; Velázquez, E. Rhizobium laguerreae sp. nov. nodulates Vicia faba on several continents. Int. J. Syst. Evol. Microbiol. 2014, 64, 242-247. [CrossRef]

23. Gaunt, M.W.; Turner, S.L.; Rigottier-Gois, L.; Lloyd-Macgilp, S.A.; Young, J.W.P. Phylogenies of atpD and recA support the small subunit rRNA-based classification of rhizobia. Int. J. Syst. Evol. Microbiol. 2001, 51, 2037-2048. [CrossRef] [PubMed]

24. Belhadi, D.; de Lajudie, P.; Ramdani, N.; Le Roux, C.; Boulila, F.; Tisseyre, P.; Boulila, A.; Benguedouar, A.; Kaci, Y.; Laguerre, G. Vicia faba L. in the Bejaia region of Algeria is nodulated by Rhizobium leguminosarum sv. viciae, Rhizobium laguerreae and two new genospecies. Syst. Appl. Microbiol. 2018, 41, 122-130. [CrossRef] [PubMed]

25. Rashid, M.H.; Gonzalez, J.; Young, J.P.; Wink, M. Rhizobium leguminosarum is the symbiont of lentils in the Middle East and Europe but not in Bangladesh. FEMS Microbiol. Ecol. 2014, 87, 64-77. [CrossRef] [PubMed]

26. Hou, B.C.; Wang, E.T.; Li, Y.; Jia, R.Z.; Chen, W.F.; Man, C.X.; Sui, X.H.; Chen, W.X. Rhizobial resource associated with epidemic legumes in Tibet. Microb. Ecol. 2009, 57, 69-81. [CrossRef] [PubMed]

27. Trovato, A.; Seno, F.; Zanardo, M.; Alberghini, S.; Tondello, A.; Squartini, A. Quorum vs. diffusion sensing: A quantitative analysis of the relevance of absorbing or reflecting boundaries. FEMS Microbiol. Lett. 2014, 352, 198-203. [CrossRef]

28. Srivastava, S.; Yodov, K.S.; Kundu, B.S. Prospects of using phosphate solubilizing Pseudomonas as biofungicide. Indian J. Microbiol. 2004, 44, 91-94. 
29. Rogel, M.A.; Ormeño-Orrillo, E.; Martinez Romero, E. Symbiovars in rhizobia reflect bacterial adaptation to legumes. Syst. Appl. Microbiol. 2011, 34, 96-104. [CrossRef]

30. Peix, A.; Ramírez-Bahena, M.H.; Velázquez, E.; Bedmar, E.J. Bacterial associations with legumes. Crit. Rev. Plant Sci. 2015, 34, 17-42. [CrossRef]

31. Broughton, W.J.; Perret, X. Genealogy of legume-Rhizobium symbioses. Curr. Opin. Plant Biol. 1999, 2, 305-311. [CrossRef]

32. Jordan, D.C., III. Rhizobiaceae. In Bergey's Manual of Systematic Bacteriology; Krieg, N.R., Holt, J.G., Eds.; Williams and Wilkins Co.: Baltimore, MD, USA, 1984; Volume 1, pp. 234-242. [CrossRef]

33. Laguerre, G.; Nour, S.M.; Macheret, V.; Sanjuan, J.; Drouin, P.; Amarger, N. Classification of rhizobia based on nodC and nifH gene analysis reveals a close phylogenetic relationship among Phaseolus vulgaris symbionts. Microbiology 2001, 147, 981-993. [CrossRef]

34. García-Fraile, P.; Mulas-García, D.; Peix, A.; Rivas, R.; González-Andrés, F.; Velázquez, E. Phaseolus vulgaris is nodulated in northern Spain by Rhizobium leguminosarum strains harboring two nodC alleles present in American Rhizobium etli strains: Biogeographical and evolutionary implications. Can. J. Microbiol. 2010, 56, 657-666. [CrossRef] [PubMed]

35. Tampakaki, A.P.; Fotiadis, C.T.; Ntatsi, G.; Savvas, D. A novel symbiovar (aegeanense) of the genus Ensifer nodulates Vigna unguiculata. J. Sci. Food Agric. 2017, 97, 4314-4325. [CrossRef] [PubMed]

36. Robledo, M.; Rivera, L.; Jiménez-Zurdo, J.I.; Rivas, R.; Dazzo, F.; Velázquez, E.; Martínez-Molina, E.; Hirsch, A.M.; Mateos, P.F. Role of Rhizobium endoglucanase $\mathrm{CelC}_{2}$ in cellulose biosynthesis and biofilm formation on plant roots and abiotic surfaces. Microb. Cell Fact. 2012, 11, 125. [CrossRef] [PubMed]

37. Jiménez-Gómez, A.; Flores-Félix, J.D.; García-Fraile, P.; Mateos, P.F.; Menéndez, E.; Velázquez, E.; Rivas, R. Probiotic activities of Rhizobium laguerreae on growth and quality of spinach. Sci. Rep. 2018, 8, 295. [CrossRef]

38. Downie, J.; González, J. Cell-to-Cell communication in rhizobia: Quorum Sensing and Plant Signaling. In Chemical Communication among Bacteria; Winans, S., Bassler, B., Eds.; ASM Press: Washington, DC, USA, 2008; pp. 213-232. [CrossRef]

39. Calatrava-Morales, N.; McIntosh, M.; Soto, M.J. Regulation mediated by N-Acyl homoserine lactone quorum sensing signals in the Rhizobium-Legume symbiosis. Genes 2018, 9, 263. [CrossRef]

40. Lithgow, J.K.; Danino, V.E.; Jones, J.; Downie, J.A. Analysis of N-acyl homoserine-lactone quorum-sensing molecules made by different strains and biovars of Rhizobium leguminosarum containing different symbiotic plasmids. Plant Soil 2001, 232, 3-12. [CrossRef]

41. Beringer, J.E.; Brewin, N.J.; Johnston, A.W.B. The genetic analysis of Rhizobium in relation to symbiotic nitrogen fixation. Heredity 1980, 45, 161-186. [CrossRef]

42. Velázquez, E.; Carro, L.; Flores-Félix, J.D.; Menéndez, E.; Ramírez-Bahena, M.H.; Peix, A. Bacteria-inducing legume nodules involved in the improvement of plant growth, health and nutrition. In Microbiome in Plant Health and Disease; Kumar, V., Prasad, R., Kumar, M., Choudhary, D., Eds.; Springer: Singapore, 2019; pp. 79-104. [CrossRef]

43. García-Fraile, P.; Carro, L.; Robledo, M.; Ramírez-Bahena, M.H.; Flores-Félix, J.D.; Fernández, M.T.; Mateos, P.F.; Rivas, R.; Igual, J.M.; Martínez-Molina, E.; et al. Rhizobium promotes non-legumes growth and quality in several production steps: Towards a biofertilization of edible raw vegetables healthy for humans. PLoS ONE 2012, 7, e38122. [CrossRef]

44. Flores-Félix, J.D.; Menéndez, E.; Rivera, L.P.; Marcos-García, M.; Martínez-Hidalgo, P.; Mateos, P.; Martínez-Molina, E.; Velázquez, E.; García-Fraile, P.; Rivas, R. Use of Rhizobium leguminosarum as a potential biofertilizer for Lactuca sativa and Daucus carota crops. J. Plant Nutr. Soil Sci. 2013, 176, 876-882. [CrossRef]

45. Ayuso-Calles, M.; García-Estévez, I.; Jiménez-Gómez, A.; Flores-Félix, J.D.; Escribano-Bailón, M.T.; Rivas, R. Rhizobium laguerreae improves productivity and phenolic compound content of lettuce (Lactuca sativa L.) under saline stress conditions. Foods 2020, 9, 1166. [CrossRef]

46. Lindström, K.; Mousavi, S.A. Effectiveness of nitrogen fixation in rhizobia. Microb. Biotechnol. 2019, 13, 1314-1335. [CrossRef]

47. Parsons, R.; Stanforth, A.; Raven, J.A.; Sprent, J.I. Nodule growth and activity may be regulated by a feedback mechanism involving phloem nitrogen. Plant Cell Environ. 1993, 16, 125-136. [CrossRef]

48. Murray, J.D.; Liu, C.W.; Chen, Y.; Miller, A.J. Nitrogen sensing in legumes. J. Exp. Bot. 2017, 68, 1919-1926. [CrossRef] 
49. Rigaud, J.; Puppo, A. Indole-3-acetic acid catabolism by soybean bacteroids. J. Gen. Microbiol. 1975, 88, 223-228. [CrossRef]

50. Rivas, R.; Peix, A.; Mateos, P.F.; Trujillo, M.E.; Martinez-Molina, E.; Velázquez, E. Biodiversity of populations of phosphate solubilizing rhizobia that nodulate chickpea in different Spanish soils. Plant Soil 2006, 287, 23-33. [CrossRef]

51. Carro, L.; Spröer, C.; Alonso, P.; Trujillo, M.E. Diversity of Micromonospora strains isolated from nitrogen fixing nodules and rhizosphere of Pisum sativum analyzed by multilocus sequence analysis. Syst. Appl. Microbiol. 2012, 35, 73-80. [CrossRef]

52. Altschul, S.F.; Gish, W.; Miller, W.; Myers, E.W.; Lipman, D.J. Basic local alignment search tool. J. Mol. Biol. 1990, 215, 403-410. [CrossRef]

53. Thompson, J.D.; Gibson, T.J.; Plewniak, F.; Jeanmougin, F.; Higgins, D.G. The clustalX windows interface: Flexible strategies for multiple sequence alignement aided by quality analysis tools. Nucleic Acids Res. 1997, 24, 4876-4882. [CrossRef]

54. Kimura, M. A simple method for estimating evolutionary rates of base substitutions through comparative studies of nucleotide sequences. J. Mol. Evol. 1980, 16, 111-120. [CrossRef]

55. Saitou, N.; Nei, M. A neighbour-joining method: A new method for reconstructing phylogenetics trees. Mol. Biol. Evol. 1987, 44, 406-425. [CrossRef]

56. Kumar, S.; Stecher, G.; Tamura, K. MEGA7: Molecular Evolutionary Genetics Analysis Version 7.0 for Bigger Datasets. Mol. Biol. Evol. 2016, 3, 1870-1874. [CrossRef] [PubMed]

57. Vincent, J.M. A Manual for the Practical Study of the Root-Nodule Bacteria; IBP Handbook 15; Blackwell Scientific Publications: Oxford, UK, 1970; pp. 1-13. [CrossRef]

58. Marenda, M.; Zanardo, M.; Trovato, A.; Seno, F.; Squartini, A. Modeling quorum sensing trade-offs between bacterial cell density and system extension from open boundaries. Sci. Rep. 2016, 6, 39142. [CrossRef] [PubMed]

59. Mateos, P.F.; Jimenez-Zurdo, J.I.; Chen, J.; Squartini, A.S.; Haack, S.K.; Martinez-Molina, E.; Hubbell, D.H.; Dazzo, F.B. Cell-associated pectinolytic and cellulolytic enzymes in Rhizobium leguminosarum biovar trifolii. Appl. Environ. Microbiol. 1992, 58, 1816-1822. [CrossRef] [PubMed]

60. Peix, A.; Rivas-Boyero, A.A.; Mateos, P.F.; Rodríguez-Barrueco, C.; Martínez-Molina, E.; Velázquez, E. Growth promotion of chickpea and barley by a phosphate solubilizing strain of Mesorhizobium mediterraneum under growth chamber conditions. Soil Biol. Biochem. 2001, 33, 103-110. [CrossRef]

61. Schwyn, B.; Neilands, J.B. Universal chemical assay for the detection and determination of siderophores. Anal. Biochem. 1987, 160, 47-56. [CrossRef]

62. Alexander, D.B.; Zuberer, D.A. Use of chrome azurol S reagents to evaluate siderophore production by rhizosphere bacteria. Biol. Fertil. Soils 1991, 12, 39-45. [CrossRef]

63. O’Hara, G.W.; Goss, T.J.; Dilworth, M.J.; Glenn, A.R. Maintenance of intracellular pH and acid tolerance in Rhizobium meliloti. Appl. Environ. Microbiol. 1989, 55, 1870-1876. [CrossRef]

64. Khalid, A.; Arshad, M.; Zahir, Z.A. Screening plant growth-promoting rhizobacteria for improving growth and yield of wheat. J. Appl. Microbiol. 2004, 96, 473-480. [CrossRef]

Publisher's Note: MDPI stays neutral with regard to jurisdictional claims in published maps and institutional affiliations.

(C) 2020 by the authors. Licensee MDPI, Basel, Switzerland. This article is an open access article distributed under the terms and conditions of the Creative Commons Attribution (CC BY) license (http://creativecommons.org/licenses/by/4.0/). 